\title{
Estimation of Phosphorus Release Rate by Bacterivorous Flagellates in Lake Biwa
}

\begin{abstract}
Shin-ichi NAKANO
Abstract

In situ phosphorus release rates of bacterivorous flagellates were estimated in Lake Biwa to clarify their contribution to $\mathrm{P}$ cycling. Density of the flagellates ranged from

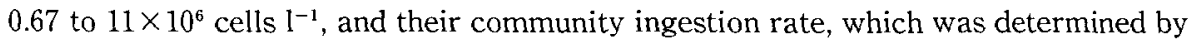
the fluorescently labeled bacteria method, varied seasonally from 0.20 to $23 \times 10^{8}$ bacteria $\cdot 1^{-1} \cdot \mathrm{d}^{-1}$. Bacterial carbon content showed seasonal variation $(0.53$ to $15 \mathrm{fmol}$ $\mathrm{C}$ cell $\left.^{-1}\right)$, but bacterial $\mathrm{C}$ : $\mathrm{P}$ molar ratio was relatively invariant $(106 \pm 25, \mathrm{n}=24)$. In situ $\mathrm{P}$ release rate by the flagellates was estimated, based on these data and a stoichiometric model. The validity of the estimates was confirmed by incubation experiments using bacteria with $\mathrm{C}: \mathrm{P}$ ratios of 30 to 103. In four of five experiments, $\mathrm{P}$ release rates estimated from the model coincided well with those from another method. In situ $\mathrm{P}$ release rate ranged from 0.11 to $59 \mathrm{nmol} \mathrm{P} \cdot \mathrm{l}^{-1} \cdot \mathrm{d}^{-1}$, accounting for 4.2 to $31 \%$ of $\mathrm{P}$ required for phytoplankton primary production. This result suggests that bacterivorous flagellates are important, if not major, $\mathrm{P}$ suppliers in the lake, and that other $\mathrm{P}$ sources are needed for the lake phytoplankton.
\end{abstract}

Key words : bacterivorous flagellates, $\mathrm{P}$ release rate, $\mathrm{P}$ limited bacteria, Lake Biwa

\section{Introduction}

Previous studies have demonstrated phosphorus limitation for phytoplankton in many lakes (SaKamoto, 1966 ; Schindler, 1978 ; Tezuka,1985). Some biological processes can free phytoplankton from $\mathrm{P}$ limitation, e.g., bacterial decomposition of organic matter and excretion of zooplankton.

However, lake seston are often poor in $\mathrm{P}$ ( $c f$. Tezuka, 1985; Nakanishi et al., 1990), so that $\mathrm{P}$ release through bacterial decomposition of the seston may be negligible (Теzuкa, 1990). Furthermore, $\mathrm{P}$ uptake by bacteria is swifter than that by phytoplankton when $\mathrm{P}$ exists in low concentrations (CURrie and KalfF, 1984). Hence, bacteria are consumers rather than suppliers of $\mathrm{P}$ in lakes.

In addition, bacteria serve as large $\mathrm{P}$ pools, relative to $\mathrm{P}$ in other planktonic organisms (VADSTEIN et al., 1988; Watanabe, 1990). Regeneration of $\mathrm{P}$ preserved in bacterial cells, therefore, can furnish an important $\mathrm{P}$ supply for phytoplankton. Among bacterivory of zooplankton, that of heterotrophic flagellates accounts for a significant portion of bacterial biomass losses (NAGATA, 1988; SANDERS et al., 1989). In addition to this, bacterivorous flagel. lates have higher $\mathrm{P}$ release rates per body weight than metazoan zooplankton (ANDERSEN et al., 1986). For these reasons, flagellates have been considered to be important P suppliers for phytoplankton in lakes (VADstein et al., 1993).

However, there is circumstantial evidence that bacterivorous flagellates do not always serve as important $\mathrm{P}$ suppliers in lakes. Nutrient release by heterotrophs depends not only on the quantity but also the quality of their food. Recent theoretical studies suggest that the amount of $\mathrm{P}$ released by heterotrophs is closely associated with the $\mathrm{C}: \mathrm{P}$ or $\mathrm{N}: \mathrm{P}$ ratios of food relative to their stoichiometry (STERNER, 1990; Hessen and Andersen, 1992). URABe (1993) demonstrated that changes in $\mathrm{N}: \mathrm{P}$ release 
ratios by a zooplankton community dominated by Daphnia were consistent with those in N : P ratios of food seston. Similar regulation of assimilation and release of $\mathrm{P}$ was reported for bacteria, although bacterial elemental ratios were variable (Tezuka, 1990). Phosphorus release by flagellates also depends partly on the quantity and quality of prey (Goldman et al., 1987; JÜRGENS and GÜDE, 1990). Interestingly, NAKANO (1994a) demonstrated that the inorganic $\mathrm{P}$ release rate by Spumella sp. was reduced to a negligible level when $\mathrm{C}$ : $\mathrm{P}$ molar ratios of bacteria were higher than 70 . Since $C$ : $\mathrm{P}$ molar ratios of lake seston in a bacterial sized fraction can, in fact, exceed 70 (Watanabe, 1990), $\mathrm{P}$ release by flagellates which ingest bacteria with such high $\mathrm{C}$ : $\mathrm{P}$ ratios may be low. Furthermore, nutrient release by an isolated flagellate is more efficient for $\mathrm{N}$ than for $\mathrm{P}$ in experimental systems (Goldman et al., 1987; Nakano, 1994b).

This study examined the $\mathrm{P}$ release rate by bacterivorous flagellates in $\mathrm{P}$ limited Lake Biwa to clarify the contribution of flagellates to phytoplankton primary production. $\mathrm{C}: \mathrm{P}$ ratios of bacteria and ingestion rates of flagellates were measured simultaneously. Based on these data, the $P$ release rate by flagellates was calculated from a stoichiometric model established by CARON (1991). Incubation experiments were also carried out with enriched filtered lake water. $P$ release rates estimated from the model were then compared with those from changes in dissolved inorganic $\mathrm{P}$ concentration during the incubation period to check the validity of the stoichiometric model.

\section{Materials and methods}

\section{2-1. Sampling stations}

Lake Biwa is located in the center of Honshu Island, Japan $\left(35^{\circ} 10^{\prime} \mathrm{N}, 136^{\circ} 00^{\prime} \mathrm{E}\right.$, altitude $85 \mathrm{~m}$ ). Samples were collected monthly at two stations from July 1992 to June 1993: Station $\mathrm{NB}$ (water depth, ca. $75 \mathrm{~m}$ ) was located in a pelagic area of the mesotrophic north basin of the lake $4 \mathrm{~km}$ offshore ( $\left.35^{\circ} 13^{\prime} \mathrm{N}, 136^{\circ} 00^{\prime} \mathrm{E}\right)$, and Station SB (water depth, ca. $4 \mathrm{~m}$ ) was located in the area of the eutrophic south basin $2 \mathrm{~km}$ offshore $\left(35^{\circ} 05^{\prime} \mathrm{N}, 135^{\circ} 54^{\prime} \mathrm{E}\right)$. Additional experiments were also conducted monthly at Station Wani, which was in a pelagic area of the north basin $3 \mathrm{~km}$ offshore $\left(35^{\circ} 11^{\prime} \mathrm{N}, 135^{\circ} 56^{\prime}\right.$ E), from July to November 1992. All water samples were collected at a depth of 0.5 to $1 \mathrm{~m}$ (Stations NB and SB) and $2.5 \mathrm{~m}$ (Station Wani) with a modified 10-liter Van Dorn water sampler.

\section{2-2. Determination of microbial den- sities and bacterivory}

On shipboard, a $50 \mathrm{ml}$ portion of the water samples was fixed with glutaraldehyde (final conc. of $1 \%$ ). Bacteria were counted by the acridine orange direct count method (HoBBIE $e t$ al., 1977). Colourless flagellates were enumerated by the fluorescein isothiocyanate (FITC) staining method (SHERr and SHERR, 1983).

Ingestion rate of bacterivorous flagellates was determined with fluorescently labeled bacteria (FLB) (SHERr et al., 1987) made of a minicell-producing mutant strain of Escherichia coli. This bacterium was cultured in a liquid medium, and minicells were separated using the method of Christen et al. (1983). These minicells are spherical with a diameter of 0.5 to $1 \mu \mathrm{m}$.

FLB were added to water samples $(100 \mathrm{ml})$ at a density of $3-5 \times 10^{5}$ cells $\cdot \mathrm{ml}^{-1}(<10 \%$ of in situ bacterial density). The FLB-spiked water samples were incubated at in situ temperature under dim light conditions. After $8 \mathrm{~min}$ of incubation, subsamples were fixed with $4 \%$ ice-cold, buffered glutaraldehyde, which is an effective fixative to reduce the egestion of bacteria ingested into a food vacuole of the flagellates (SANDERS et al., 1989). The flagellates were stained with FITC, and FLB in food vacuoles of the flagellates were counted with an epifluorescence microscope. At least 200 cells of the flagellates were examined. Time-zero control was prepared to count for FLB adsorbed to the flagellates.

\section{2-3. Elemental content and ratio of lake bacteria}

Two, 8-10 liter portions of water samples were filtered through Whatman $\mathrm{GF} / \mathrm{C}$ filters. The filtrates were then filtered again through 
Whatman GF/F filters. These filters were precombusted at $450^{\circ} \mathrm{C}$ for $2 \mathrm{~h}$. I assumed any $\mathrm{C}$ and $P$ of the seston retained on the GF/F filter was that of the bacteria. The amount of $\mathrm{C}$ on the $\mathrm{GF} / \mathrm{F}$ filter $\left(\mathrm{C}_{\mathrm{GF} / \mathrm{F}}, \mathrm{nmol} \mathrm{C}\right)$ was determined with a $\mathrm{CHN}$-analyzer (Yanaco, MT-3), and that of $\mathrm{P}\left(\mathrm{P}_{G F / F}\right.$, nmol $\left.\mathrm{P}\right)$ using the method of Menzel and Corwin (1965). Both GF/C and GF/ $F$ filtrates were fixed with glutaraldehyde to enumerate bacteria.

Carbon content of bacteria $\left(C_{B}, n\right.$ mol $C$. cell $^{-1}$ ) was determined as

$$
\mathrm{C}_{\mathrm{B}}=\mathrm{C}_{\mathrm{GF} / \mathrm{F}} /\left(\mathrm{B}_{\mathrm{GF} / \mathrm{C}}-\mathrm{B}_{\mathrm{GF} / \mathrm{F}}\right)
$$

where $B_{G F / C}$ and $B_{G F / F}$ were bacterial densities in $\mathrm{GF} / \mathrm{C}$ and $\mathrm{GF} / \mathrm{F}$ filtrates, respectively. The same equation was also used when the bacterial $\mathrm{P}$ content $\left(\mathrm{P}_{\mathrm{B}}, \mathrm{nmol} \mathrm{P} \cdot \mathrm{cell}^{-1}\right)$ was calculated. In this case, $C_{G F / F}$ was replaced by $P_{G F / F}$ in the equation.

Whatman $\mathrm{GF} / \mathrm{F}$ filters were sometimes unable to retain the lake bacteria efficiently; percentages of the bacteria retained on the filters to in situ bacterial density were $3.7-70 \%$ (mean 19\%) at Station NB and 1.6-40\% (mean $14 \%)$ at Station SB.

\section{2-4. Lake water incubation experiments}

A 10-liter water sample was filter-sterilized through a Gelman capsule filter (Culture capsule, pore size $0.2 \mu \mathrm{m})$. Each 5-liter aliquot of the filtrate was poured into 10 -liter glass bottles. A 1-liter aliquot of the water sample was filtered through a Whatman GF/C filter, and each $500 \mathrm{ml}$ of the filtrate was added as inocula to the sterilized filtrate. Two cultures were prepared : one with no further addition of nutrients (control) ; another supplemented with glucose $5 \mu \mathrm{mol} \mathrm{C} \cdot \mathrm{l}^{-1}, \mathrm{NH}_{4} \mathrm{Cl} 1 \mu \mathrm{mol} \mathrm{N} \cdot \mathrm{l}^{-1}$ and $\mathrm{K}_{2}$ $\mathrm{HPO}_{4} 0.5 \mu \mathrm{mol} \mathrm{P} \cdot 1^{-1}(\mathrm{C}: \mathrm{N}: \mathrm{P}=10: 2: 1)$. Cultures were incubated at $25^{\circ} \mathrm{C}$ in the dark. Subsamples were withdrawn at various intervals to determine densities of bacteria and flagellates as well as concentrations of dissolved inorganic phosphorus (DIP), the last of which were measured using the method of MurPhy and RiLeY (1962). For the experiments of August and September 1993, I also measured concentrations of total dissolved phosphorus (TDP) using the method of MENzel and CoRwin (1965).
When the bacteria had attained the stationary phase, and flagellates had appeared $(\sim 1000$ cells $\left.\cdot \mathrm{ml}^{-1}\right), 2$-liters of the culture were filtered through a precombusted Whatman GF/F filter to measure bacterial carbon content on the filter with the $\mathrm{CHN}$-analyzer. Bacterial $\mathrm{P}$ content was determined as the difference between the concentration of total phosphorus (TP) in the unfiltered culture and the GF/F filtrate, using the method of MENZEL and CORWIN (1965).

\section{2-5. Estimation of release rate}

From the experimental data, the phosphorus release rate by bacterivorous flagellates $(E$, fmol $\mathrm{P} \cdot$ cell $^{-1} \cdot \mathrm{h}^{-1}$ ) was calculated in two ways. One was as follows:

$$
\mathrm{E}=\left(\mathrm{P}_{2}-\mathrm{P}_{1}\right) /\left(\mathrm{T} \times \mathrm{D}_{\mathrm{Fm}}\right)
$$

where $P_{1}$ and $P_{2}$, concentrations of DIP at the onset and end of the exponential growth phase of the flagellates (fmol $\left.\mathrm{P} \cdot \mathrm{I}^{-1}\right) ; \mathrm{T}$, time (hours) of the exponential growth phase of the flagellates; $\mathrm{D}_{\mathrm{F} m}\left(\right.$ cells $\left.\cdot 1^{-1}\right)$, mean flagellate density determined according to Heingokel (1978) as

$$
\mathrm{D}_{\mathrm{Fm}}=\left(\mathrm{D}_{2}-\mathrm{D}_{\mathrm{I}}\right) /\left(\operatorname{lnD}_{2}-\ln \mathrm{D}_{1}\right)
$$

where $D_{1}$ and $D_{2}$ were densities of the flagellates (cells $\cdot 1^{-1}$ ) at the onset and end of the exponential growth phase, respectively.

The other was an estimation using the stoichiometric model proposed by CARON (1991):

$$
\begin{aligned}
E^{\prime}= & R \times(1-\mathrm{Y})^{-1} \times\left\{\left(\mathrm{C}: \mathrm{P}_{\text {pres }}\right)^{-1}\right. \\
& \left.-\mathrm{Y} \times\left(\mathrm{C}: \mathrm{P}_{\text {flag }}\right)^{-1}\right\}
\end{aligned}
$$

where $\mathrm{E}^{\prime}, \mathrm{P}$ release rate by flagellates (fmol $\mathrm{P}$. cell $\left.^{-1} \cdot \mathrm{h}^{-1}\right) ; \mathrm{R}$, respiration rate $\left(\mathrm{fmol} \mathrm{C} \cdot \mathrm{cell}^{-1}\right.$. $\left.\mathrm{h}^{-1}\right)$; $\mathrm{Y}$, growth yield in terms of carbon; $\mathrm{C}$ : $P_{\text {prey }}$ and $C: P_{\text {flag }}, C: P$ molar ratios of the bacteria and flagellates, respectively. In the equation, I assumed that the growth yield and C : P molar ratio of the flagellates were, respectively, 0.32 and 83 (NAKANo, 1994a), and that all carbon ingested by flagellates was used for their production and respiration. The latter assumption means that the part " $\mathrm{R} \times(1-\mathrm{Y})^{-1}$ " in the equation equals the ingestion rate based on carbon $\left(I_{c}\right.$, fmol $\left.\mathrm{C} \cdot \mathrm{cell}^{-1} \cdot \mathrm{h}^{-1}\right)$. Thus, the equation could be expressed as

$$
E^{\prime}=I_{C} \times\left\{\left(C: P_{\text {prey }}\right)^{-1}-0.003855\right\}
$$

$\mathrm{I}_{c}$ was calculated as a multiplication of the ingestion rate $\left(\mathrm{I}_{\mathrm{G}}\right.$, bacteria cell $\left.{ }^{-1} \cdot \mathrm{h}^{-1}\right)$ by the 
bacterial carbon content $\left(\mathrm{C}_{\mathrm{B}}{ }^{\prime}\right.$, fmol $\left.\mathrm{C} \cdot \mathrm{cell}^{-1}\right)$. $\mathrm{I}_{\mathrm{G}}$ was determined as

$$
I_{G}=\left(B_{2}-B_{1}\right) /\left(T \times D_{F m}\right)
$$

where $B_{1}$ and $B_{2}$, bacterial densities (cells $\cdot 1^{-1}$ ) at the onset and end of the exponential growth phase of the flagellates, assuming no growth by bacteria in the stationary phase. $\mathrm{C}_{\mathrm{B}}$ ' was determined by dividing the concentrations of particulate carbon ( $\mathrm{fmol} \mathrm{C} \cdot \mathrm{l}^{-1}$ ) at the onset of the exponential growth phase of the flagellates by $\mathrm{B}_{1}$.

For field data, the $P$ release rate by bacterivorous flagellates in Lake Biwa $\left(\mathrm{E}_{\mathrm{l}}\right.$, nmol $\mathrm{P}$. $\left.1^{-1} \cdot \mathrm{d}^{-1}\right)$ was also estimated using Eq. (5). In this case, $C: P_{\text {prey }}$ was replaced with the $C: P$ molar ratio of in situ bacteria for each month. Community ingestion rates of the flagellates determined by the FLB method were used and converted into the amount of carbon (nmol C. $\mathrm{I}^{-1} \cdot \mathrm{d}^{-1}$ ). For the conversion, I multiplied the ingestion rate by the in situ bacterial carbon content $\left(\mathrm{C}_{\mathrm{B}}\right.$, see Eq.(1)) in the estimation of $\mathrm{P}$ release rates at Stations $\mathrm{NB}$ and SB. For Station Wani, I used a representative bacterial carbon content (median $2.42 \mathrm{fmol} \mathrm{C} \cdot \mathrm{cell}^{-1}$ ) and a mean $\mathrm{C}: \mathrm{P}$ ratio of bacteria at Station NB (110), since I was unable to determine carbon content and $\mathrm{C}: \mathrm{P}$ ratio of bacteria at Station Wani.

\section{Results}

\section{3-1. Microbial densities, elemental ratios and bacterivory}

Seasonal changes in bacterial density at Station NB were variable: 3.2 to $11 \times 10^{9}$ cells . $1^{-1}$ (Fig. 1A) but the density was relatively low from January to March 1993. Bacterial density at Station SB was relatively high from September to November 1992, ranging from 15 to $19 \times$ $10^{9}$ cells $\cdot 1^{-1}$. It decreased rapidly from December, was $<5 \times 10^{9}$ cells $\cdot 1^{-1}$ until March, and increased again from April. The density of flagellates at both stations did not show clear seasonal trends, fluctuating between 1.0 to $4.0 \times$ $10^{6}$ cells $\cdot 1^{-1}$ at Station NB, and between 2.0 to $5.0 \times 10^{6}$ cells $\cdot 1^{-1}$ at Station SB (Fig. 1B). At Station SB, flagellate density reached $11 \times 10^{6}$ cells $\cdot 1^{-1}$ in April 1993. Densities of bacteria and
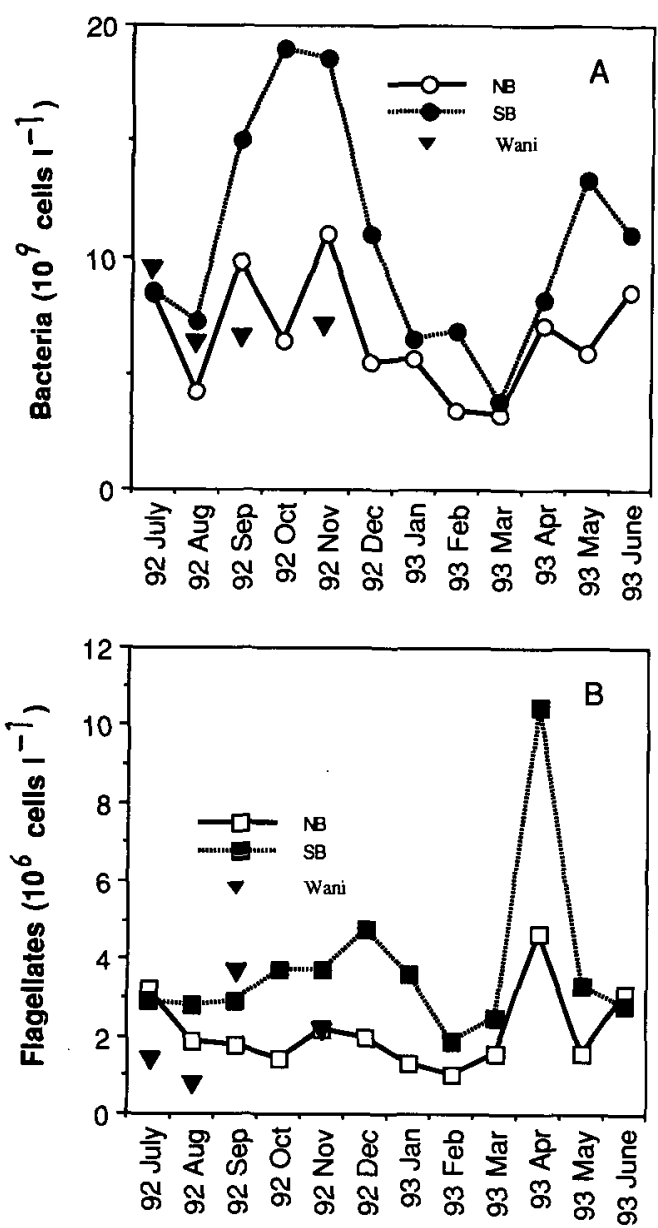

Fig. 1. Seasonal changes in densities of bacteria (A) and flagellates (B) at Stations NB, SB and Wani in Lake Biwa.

flagellates at Station SB were higher than those at Station NB, and those at Station Wani fell between the ranges from those two stations.

Bacterial carbon content showed large variations from 0.53 to $15 \mathrm{fmol} \mathrm{C \cdot cell-1}$ at Station $\mathrm{NB}$, and from 0.68 to $9.3 \mathrm{fmol} \mathrm{C} \cdot \mathrm{cell}^{-1}$ at Station SB (Fig. 2A). At both stations, bacterial carbon was relatively low from January to March 1993, and variable during other period of the survey. $\mathrm{C}: \mathrm{P}$ ratios of the bacteria ranged from 72 to 153 at Station NB, and from 78 to 138 at Station SB (Fig. 2B). These ratios were relatively high from November to February at Station NB, indicating that bacteria were $P$ limited during that period. However, bacterial $\mathrm{C}: \mathrm{P}$ ratios at Station $\mathrm{SB}$ did not show any 

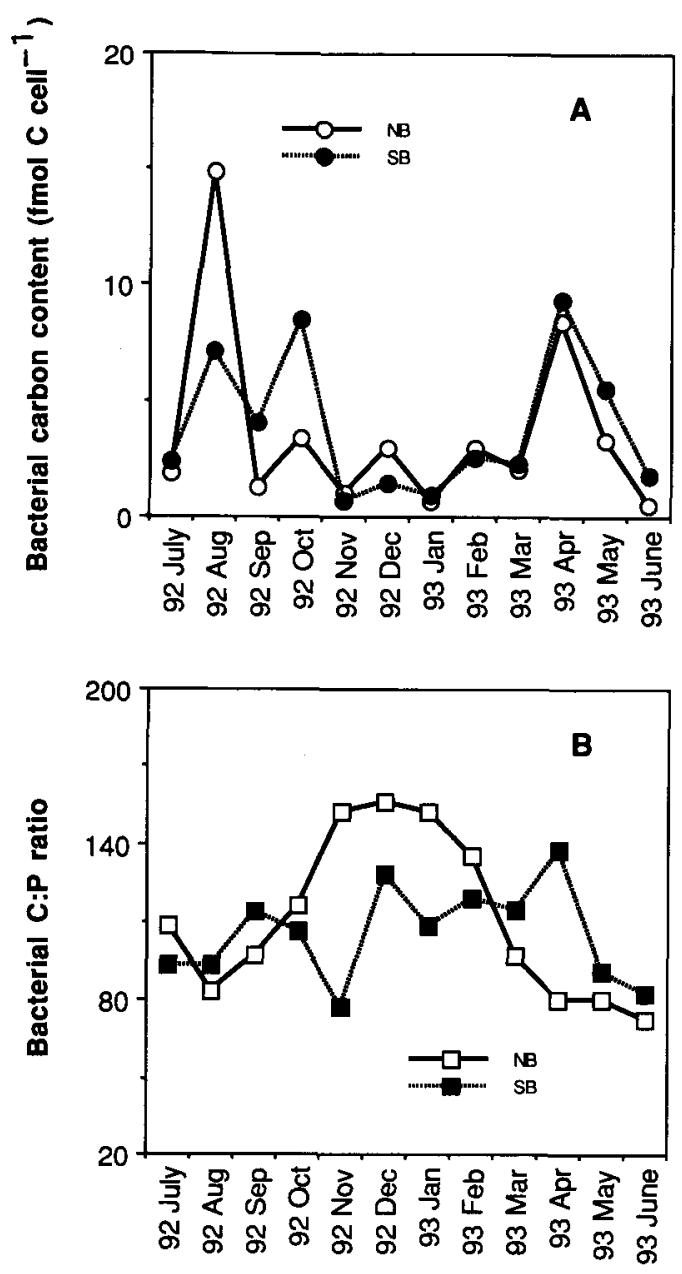

Fig. 2. Seasonal changes in carbon content per 1 bacterial cell $(\mathrm{A})$ and bacterial $\mathrm{C}$ : $\mathrm{P}$ ratio (B) at two stations in Lake Biwa.

seasonal trends.

The community ingestion rate of bacteria by flagellates fluctuated from 0.2 to $8.8 \times 10^{8}$ bacteria $\cdot 1^{-1} \cdot \mathrm{d}^{-1}$ at Station NB, and from 0.9 to $23 \times 10^{8}$ bacteria $\cdot 1^{-1} \cdot \mathrm{d}^{-1}$ at Station SB (Fig. 3). At Station SB, the community ingestion rate was relatively high from July to December 1992, decreased to $<3 \times 10^{8}$ bacteria $\cdot 1^{-1} \cdot \mathrm{d}^{-1}$ from January to March 1993, and increased again from April. The rates at Station NB were much lower than those at Station SB except in December 1992, but the pattern of change was somewhat similar to that at Station SB. The rates at Station Wani were in the same range as those at Stations SB and NB, fluctuating from

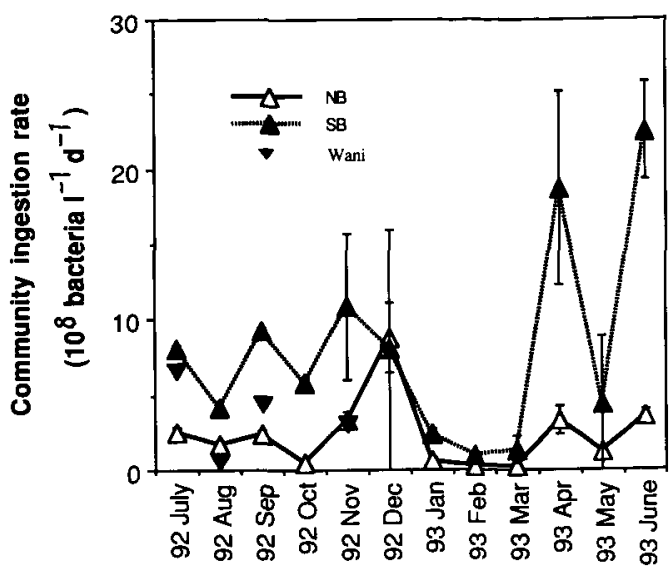

Fig. 3. Seasonal changes in community ingestion rate on bacteria by flagellates at three stations in Lake Biwa. Perpendicular bars indicate the standard deviation.

1.0 to $6.3 \times 10^{8}$ bacteria $\cdot 1^{-1} \cdot \mathrm{d}^{-1}$.

3-2. Lake water incubation experiments

To check the validity of the method of estimating the $P$ release rate by bacterivorous flagellates, the rate of dissolved inorganic phosphorus (DIP) was estimated using the stoichiometric model of CARON (1991) (see Eq. (5)). This was then compared with the DIP release rate calculated with Eq. (2) in incubation experiments with enriched lake water filtrate. Figure 4 shows a representative result obtained in August 1992. Bacterial proliferation occurred during the first 2 days, followed by growth of flagellates which grazed on the bacteria in the nutrient-supplemented culture. No flagellates was detected in control cultures, and concentrations of DIP in the cultures were below the detection limit $\left(<0.10 \mu \mathrm{mol} \mathrm{P} \cdot \mathrm{l}^{-1}\right)$ throughout the experimental period (data not shown). DIP was utilized rapidly by bacteria during the first 2 days in the nutrient-supplemented culture, and thereafter concentrations of DIP increased with an increase in growth of flagellates. The increase in DIP concentrations in the culture was apparently due to $\mathrm{P}$ release by flagellates (Fig. 4). A similar pattern of growth and $\mathrm{P}$ release by flagellates was observed in all experiments conducted five times, although there were differences in growth rates of flagellates and changes in DIP concentrations. To 
examine the release of dissolved organic phosphorus (DOP) by flagellates, I also measured concentrations of total dissolved phosphorus (TDP) in the experiments performed in August and September 1993. Although TDP concentrations increased consistently with the growth of flagellates, this increase was due to concentrations of DIP. Hence I concluded that DOP release by flagellates was negligible.
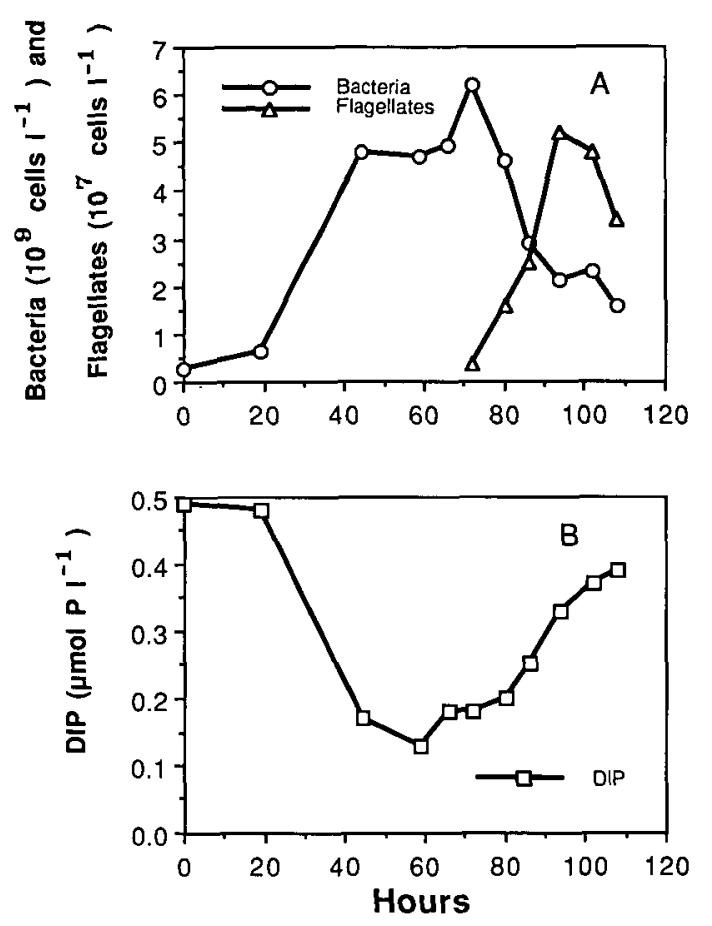

Fig. 4. Results of lake water incubation experiments conducted in August 1992. Changes in densities of bacteria and flgellates (A) and concentrations of dissolved inorganic phosphorus (DIP) (B) in the nutrient-supplemented culture.
Bacterial C: P ratios in the nutrient-supplemented culture ranged from 30 to 103 (Table 1). $\mathrm{P}$ release rate estimated with $\mathrm{Eq}$. (2) ranged from 0.20 to $0.48 \mathrm{fmol} \mathrm{P} \cdot$ cell $^{-1} \cdot \mathrm{h}^{-1}$, and that with Eq. (5) from 0.21 to $1.1 \mathrm{fmol} \mathrm{P} \cdot \mathrm{cell}^{-1} \cdot \mathrm{h}^{-1}$. The estimates from Eq. (5) coincided well with those from Eq. (2) with one exception : a 2.9fold difference was detected between the two in the experiment conducted in August 1992. Although the value $1.1 \mathrm{fmol} \mathrm{P} \cdot \mathrm{cell}^{-1} \cdot \mathrm{h}^{-1}$ obtained in August 1992 was extremely high compared with other estimates from Eq. (5), the value was not rejected in the estimates from Eq. (5) by Smirnoff test. Finally, I examined a difference between the estimates from Eq. (2) and Eq. (5) by Student's t-test, and found it to be insignificant $(p=0.5)$. The results indicate that the model was applicable to an estimation of $P$ release rate by flagellates grazing on bacteria.

\section{3-3. Estimation of in situ phosphorus release by flagellates}

At Station NB, the $P$ release rate by bacterivorous flagellates estimated from Eq. (5) ranged from 0.11 to $24 \mathrm{nmol} \mathrm{P} \cdot \mathrm{l}^{-1} \cdot \mathrm{d}^{-1}$, and seasonal trends in the rate were not found (Fig. 5). The $P$ release rate estimated at Station $S B$ ranged from 1.2 to $59 \mathrm{nmol} \mathrm{P} \cdot \mathrm{l}^{-1} \cdot \mathrm{d}^{-1}$. Its seasonal changes were somewhat similar to those in the community ingestion rate of the flagellates: the $\mathrm{P}$ release rate was relatively high from July to October 1992, low from November 1992 to March 1993 and rose again from April. The range of $P$ release rate by the flagellates at Station Wani was 1.3 to $8.0 \mathrm{nmol} \mathrm{P} \cdot \mathrm{l}^{-1} \cdot \mathrm{d}^{-1}$.

The contribution of $\mathrm{P}$ release rate by the flagellates was determined through a comparison with the calculated $\mathrm{P}$ requirement for phytoplankton primary production at Station

Table 1. A comparison between phosphorus release rates estimated from two methods in lake water incubation experiments.

\begin{tabular}{ccccccc}
\hline & July 1992 & Aug. 1992 & Sep. 1992 & Aug. 1993 & Sep. 1993 \\
\hline Bacterial C:P ratio & 103 & 30 & 75 & 53 & 76 \\
\hline $\begin{array}{c}\text { P release } \\
\text { rate }\end{array}$ & Equation(2)* & 0.27 & 0.38 & 0.33 & 0.20 & 0.48 \\
$\left(\mathrm{fmol} \mathrm{P} \cdot\right.$ cell $\left.^{-1} \cdot \mathrm{h}^{-1}\right)$ & Equation(5)* & 0.21 & $1.1^{* *}$ & 0.32 & 0.24 & 0.45 \\
\hline
\end{tabular}

* See Materials and methods.

**The value was not rejected in estimates from Eq. (5) by the Smirnoff test. 
Table 2. Primary production, phosphorus requirement of phytoplankton and phosphorus supply by flagellates at station Wani.

\begin{tabular}{|c|c|c|c|c|c|c|}
\hline & & $\begin{array}{c}\text { Primary } \\
\text { production* } \\
\left(\mu \mathrm{mol} \mathrm{C} \cdot 1^{-1} \cdot \mathrm{d}^{-1}\right)\end{array}$ & $\begin{array}{c}\text { Sestonic } \\
\text { C:P ratio* }\end{array}$ & $\begin{array}{c}\text { Required } \\
\text { phosphorus** } \\
\left(\mathrm{nmol} \mathrm{P} \cdot \mathrm{l}^{-1} \cdot \mathrm{d}^{-1}\right)\end{array}$ & $\begin{array}{l}\text { Phosphorus } \\
\text { supplied by } \\
\text { flagellates } \\
\left(\mathrm{nmol} \mathrm{P} \cdot \mathrm{I}^{-1} \cdot \mathrm{d}^{-1}\right)\end{array}$ & $\%$ supplied \\
\hline July & 1992 & 14 & 351 & 40 & 8.0 & 20 \\
\hline Aug. & 1992 & 9.6 & 325 & 30 & 1.3 & 4.2 \\
\hline Sep. & 1992 & 6.6 & 187 & 35 & 5.7 & 16 \\
\hline Nov. & 1992 & 3.3 & 292 & 11 & 3.4 & 31 \\
\hline
\end{tabular}

* The details are in $U_{R A B E}$ et al. (in press.). Primary production rate was measured at a depth of $2.5 \mathrm{~m}$ below the surface.

${ }^{*}$ Calculated by dividing a measured value of primary production by a sestonic C:P ratio.

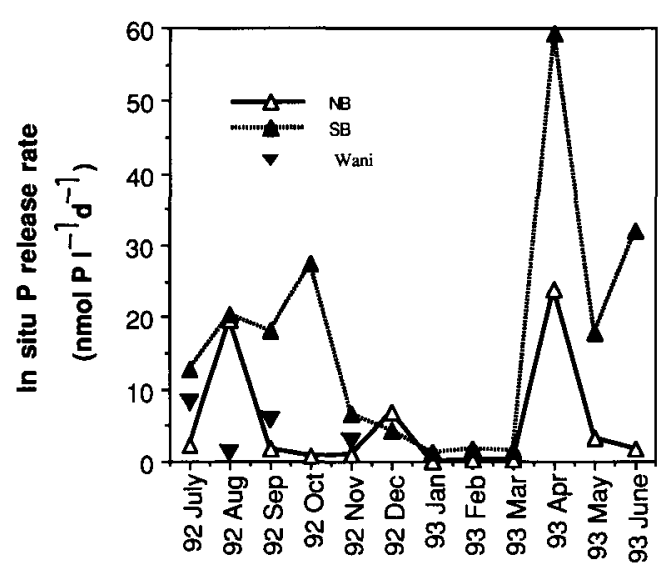

Fig. 5. Seasonal changes in estimated phosphorus release rates of bacterivorous flagellates at three stations in Lake Biwa.

Wani. Primary production rates and sestonic $\mathrm{C}: \mathrm{P}$ ratios $2.5 \mathrm{~m}$ below the surface (Table 2) were detailed in Urabe et al. (in press). Phosphorus required for primary production was calculated by dividing primary production by the sestonic $\mathrm{C}: \mathrm{P}$ ratio, and was estimated as 11 to $40 \mathrm{nmol} P \cdot 1^{-1} \cdot \mathrm{d}^{-1}$. The percentage of $\mathrm{P}$ supplied by bacterivorous flagellates of the $\mathrm{P}$ required for primary production was 4.2 to $31 \%$.

\section{Discussion}

I assumed that any carbon and phosphorus collected in the $<\mathrm{GF} / \mathrm{C},>\mathrm{GF} / \mathrm{F}$ fraction were from the bacteria in this study ( $c f$. Materials and methods). Considering the pore size of Whatman GF/C and GF/F filters, seston in the fraction ranged in size from 0.6 to $1.2 \mu \mathrm{m}$. Bacteria, algal picoplankton and bacteria-sized detrital particles can be included in this size range. NAGATA (1986) has noted that the presence of bacteria-sized detrital particles can cause an overestimation of bacterial elemental content. However, when I observed microscopic specimens stained with acridine orange, I seldom found such particles in GF/C filtrates of lake water from Stations NB and SB. Also, the biomass of algal picoplankton in the $<\mathrm{GF} /$ $\mathrm{C},>\mathrm{GF} / \mathrm{F}$ fraction is rather small compared with that of bacteria (NAGATA, 1986). For these reasons, I believe that the sestonic biomass in the $<\mathrm{GF} / \mathrm{C},>\mathrm{GF} / \mathrm{F}$ fraction can be regarded as that of bacteria. However, bacterial biomass in the bacterial fraction defined in this study represented only a small fraction of the total bacteria in Lake Biwa (cf. Materials and methods). It is necessary, therefore, to mention what bacteria was collected in the fraction. Previous studies have demonstrated that flagellates prefer to ingest particles about $1 \mu \mathrm{m}$ in size (Chrzanowski and Simek, 1990 ; Bird and KalfF, 1993). The fraction in this study $(0.6-1.2 \mu \mathrm{m})$ overlaps that range. Hence, bacteria collected in the fraction may be the preferable prey for flagellates.

The bacterial carbon content fluctuated greatly during this study: 30 -fold differences were detected at Station NB, and 14-fold differences at Station SB (Fig. 2A). However, the changes in bacterial $\mathrm{C}: \mathrm{P}$ ratio were rather small: roughly two-fold differences between 
the greatest and least values at both stations (Fig. 2B). VAdsTEIN et al. (1988) have demonstrated that $\mathrm{C}: \mathrm{P}$ ratios of bacteria in a Norwegian lake ranged from 7.2 to 76 . A mean $C$ : $P$ ratio of bacteria in the present study was $106 \pm 25$, and that in the Norwegian lake was $24 \pm 28$. Thus, the changes in $\mathrm{C}: \mathrm{P}$ ratio of bacteria in Lake Biwa are smaller than those in the Norwegian lake. Compared with a $\mathrm{C}: \mathrm{P}$ ratio obtained experimentally from an isolated flagellate (83, NAKANO, 1994a), the bacterial C: $\mathrm{P}$ ratio was relatively high. The lake bacteria may serve as qualitatively stable but $\mathrm{P}$ limited prey for flagellates. Furthermore, as already mentioned in the Introduction, the DIP release rate of an isolated flagellate was negligible when $\mathrm{C}$ : $\mathrm{P}$ molar ratios of bacteria were $>70$ (NAKANO, 1994a). This suggests that flagellates which ingest lake bacteria may concentrate $P$ by reducing the release rate of $P$.

In all the lake water incubation experiments, the $P$ release rate by bacterivorous flagellates estimated from the stoichiometric model of Caron (1991) corresponded well to that estimated from changes in concentrations of DIP and densities of the flagellates (Table 1). This result suggested that assumed values for growth yield and $\mathrm{C}$ : $\mathrm{P}$ ratio of the flagellates (0.32 and 83 , respectively) were reasonable. Indeed, the growth yield is a common value compared with what was reported previously (FENChel, 1982 ; NAGATA, 1988). In addition, Nakano (1994a) demonstrated that the $\mathrm{C}: \mathrm{P}$ ratio of an isolated flagellate was invariant despite the large variation in bacterial $\mathrm{C}: \mathrm{P}$ ratio. Further, since the model assumes that all ingested elements are completely assimilated by an animal, it can underestimate the elemental release rate of a particle-feeding animal when that animal releases indigested matter (LANDRY, 1993). If this is the case, not only DIP but also dissolved organic phosphorus (DOP) could be released in lake water incubation experiments. DOP release, however, was not detected in the experiments conducted in August and September 1993. For these reasons, I believe that the phosphorus release rate of bacterivorous flagellates can be successfully estimated in this study using the stoichiometric model. However, the estimation from the model was much higher than that from another estimation in the experiment conducted in August 1992 (Table 1). This result could have been due to the DOP release of flagellates and/ or the dominance of flagellates with a high growth yield and a low C: $\mathrm{P}$ ratio.

Phosphorus is not released during aerobic decomposition of seston in Lake Biwa (TEzuKA, 1986), but is released when $C: P$ ratios of the seston are reduced through incubation with external nutrients at low $\mathrm{C}: \mathrm{P}$ ratios (Tezuka, 1989). Bacterivorous flagellates were responsible for $\mathrm{P}$ release during the decomposition of crustacean zooplankton with a $\mathrm{C}: \mathrm{P}$ ratio of 132 in an ex situ experiment (MiYaJiMa, 1992). However, there is little information available on the in situ $\mathrm{P}$ release rate of bacterivorous flagellates in lakes. VADSTEIN et al. (1993) reported that the $\mathrm{P}$ supply of flagellates was twice as that of zooplankton in a Norwegian lake. The present study demonstrated that the $P$ release rate of flagellates accounted for 4.2 to $31 \%$ of $\mathrm{P}$ required for primary production in Lake Biwa (Table 2), The contribution of the $\mathrm{P}$ release rate by crustacean zooplankton to the $\mathrm{P}$ required was 1 to $36 \%$ in Lake Biwa (URABE $e t$ al., in press.). Thus, the contribution of the $\mathrm{P}$ supply by flagellates is almost equivalent to that of zooplankton. However, there was a large seasonal variation in the $\mathrm{P}$ release rate by the flagellates: 222-fold differences. were detected at Station NB, and 51-fold differences at Station SB (Fig. 5). Although flagellates are one of the important $\mathrm{P}$ suppliers in Lake Biwa, it is likely that their significance as $P$ suppliers in the lake varies seasonally.

Unfortunately, there is a problem in estimating the in situ $\mathrm{P}$ release rate by flagellates. Community ingestion rates presented here (Figs. 3 and 4A) are within the range of those in previous studies which used the FLB method (cf. SANDERS et al., 1989). However, that method gives relatively low ingestion rates, compared with those obtained by other methods. For example, NAGATA (1988) reported the community ingestion rate of the flagellates in Lake 
Biwa as 8.0 to $.25 \times 10^{8}$ bacteria $\cdot 1^{-1} \cdot \mathrm{d}^{-1}$, using bottle incubation experiments. The low estimates by the FLB method may be due to the use of boiled and stained E. coli minicells as surrogates. As all methods for measuring the ingestion rate of flagellates have technical problems, there is an important need to develop methods for understanding microbial cycling in freshwater and marine ecosystems.

This study suggests that the importance of bacterivorous flagellates as $\mathrm{P}$ suppliers for phytoplankton varies seasonally in Lake Biwa. Thus, phytoplankton appear to be supported not only by flagellates but also by other $P$ sources. Further studies should elucidate these $\mathrm{P}$ sources and their relative importance for phytoplankton.

\section{Acknowledgements}

I wish to thank Drs. Y.Tezuka, M.Nakanishi and other researchers at the Center for Ecological Research, Kyoto Univ. for their advice and encouragement throughout this study. Thanks are also due to Messrs. T.Ueda and T.Kortaba. $\mathrm{SHI}$ for their assistasce in the field survey, and to Dr. Y.Watanabe for his gift of a minicellproducing strain of $E$. coli. Also, I greatly appreciate the many constructive comments on this manuscript by Drs. T.NagATA and J.URABE, and correction of the English text by Dr. P. J. Beldingham. This study was partly supported by Lake Biwa Museum Research Project 93-20, Shiga Prefecture.

\section{琵琶湖における従属栄養鞭毛虫の細菌搨食 にともなうリン排出速度の見積もり}

琵琶湖における従属栄養鞭毛虫のリン排出速度 を見積もり，鞭毛虫の本湖のリン循環における重 要性を検討した。鞭毛虫の細胞密度は 0.67 少ら $11 \times 10^{6} \mathrm{cells} \cdot 1^{-1}$ の範囲にあり, 蛍光色素ラベル された細菌を用いる方法による細菌搷取速度は 0.20 から $23 \times 10^{8}$ bacteria $\cdot 1^{-1} \cdot \mathrm{d}^{-1}$ であった。細 菌の炭素含量は季節的に大きく变化した $(0.53$ ～ $\left.15 \mathrm{fmol} \mathrm{C} \cdot \mathrm{cell}^{-1}\right)$ が，その C: P 比は比較的安定 であった（モル比で $106 \pm 25, \mathrm{n}=24$ )。これらの データとある数式モデルから，鞭毛虫によるリン の排出速度を見積もった。このモデルの信頼性を 確認するために，C：P 比が 30 から 103 の細菌を
用いた培養実験を行った。この実験の 5 回のうち 4 回において，このモデルから見積もられた鞭毛 虫のリン排出速度は，他の方法で見積もられたそ れによく一致した。琵琶湖における鞭毛虫のリン 排出速度は, 0.11 から $59 \mathrm{nmol} \mathrm{P} \cdot 1^{-1} \cdot \mathrm{d}^{-1}$ と大き く変化し, 一次生産に必要なりンの 4.2 から $31 \%$ に相当した。以上の結果から，琵琶湖の鞭毛虫は 主要ではないが重要なりンの供給者であり，また 植物プランクトンの一次生産には他のリン供給源 も必要であることが考えられた。

\section{References}

Andersen, O. K., J. C. Goldman, D. A. Caron and M. R. Dennet (1986) : Nutrient cycling in a microflagellate food chain: III. Phosphorus dynamics. Mar. Ecol. Prog. Ser., 31: 47-55.

BiRd, D. F. and J. Kal.fF (1993) : Protozoan grazing and the size-activity structure of limnetic bacterial communities. Can. J. Fish. Aquat. Sci. $50: 370-380$

Caron, D. A. (1991): Evolving role of protozoa in aquatic nutrient cycles, p. 387-415. In P. C. ReID, C. M. Turley and P. H. Burkil.. [eds.] , Protozoa and their Role in Marine Processes. NATO ASI Series., Springer-Verlag.

Christen, A. A., M. L.Paul, T. Manzara and P. F. LURQUIN (1983): Rapid isolation of Escherichia coli by glass-fiber filtration : study of plasmidcoded polypeptides. Gene, $23: 195-198$.

Chrzanowski, T. H. and K. Simek (1990) : Prey-size selection by freshwater flagellated protozoa. Limnol. Oceanogr., 35 : 1429-1436.

Currie, D. J. and J.KalfF (1984): A comparison of the abilities of freshwater algae and bacteria to acquire and retain phosphorus. Limnol. Oceanogr., $29: 298-310$.

Fenchel, T. (1982): Ecology of heterotrophic microflagellates. II. Bioenergetics and growth. Mar. Ecol. Prog. Ser., 8 : 225-231.

Goldman, J. C., D. A. Caron and M. R. Dennet (1987): Nutrient cycling in a microflagellate food chain: IV. Phytoplankton-microflagellate interactions. Mar. Ecol. Prog. Ser., 38 : 75-87.

Heinbokel, J. F. (1978) : Studies on the functional role of tintinnids in the Southern California Bight. 1. Grazing and growth rates in labora. tory cultures. Mar. Biol., 47 : 177-189.

Hessen, D. O. and T. Andersen (1992): The algaegrazer interface: feedback mechanisms linked to elemental ratios and nutrient cycling. Arch. Hydrobiol. Beih. Ergebn. Limnol., 35 : 111-120. 
Hobite, J. E., R. J. Daley and S. Jasper (1977) : Use of Nuclepore filters for counting bacteria by fluorescence microscopy. Appl. Environ. Microbiol., 33 : 1225-1228.

Jürgens, K. and H. GUde (1990): Incorporation and release of phosphorus by planktonic bacteria and phagotrophic flagellates. Mar. Ecol. Prog. Ser., $59: 271-284$.

LANDRY, M. R. (1993) : Predicting excretion rates of microzooplankton from carbon metabolism and elemental ratios. Limnol. Oceanogr., 38 : $468-472$

Menzel, D. W. and N. Corwin (1965): The measurement of total phosphorus in seawater based on the liberation of organically bound fraction by persulfate oxdation. Limnol. Oceanogr., 10 : $280-282$.

Miyajima, T. (1992): Recycling of nitrogen and phosphorus from the particulate organic matter associated with the proliferation of bacteria and microflagellates. Jpn. J. Limnol., $53: 133$ -138 .

Murphy, J. and Rlley (1962): A modified single solution method for the determination of phosphorus in natural waters. Anal. Chim. Acta, $27: 31-36$.

NAGata, T. (1986) : Carbon and nitrogen content of natural planktonic bacteria. Appl. Environ. Microbiol., $52: 28-32$.

NAGATA, T. (1988): The microflagellate-picoplankton food linkage in the water column of Lake Biwa. Limnol.Oceanogr., 33 : 504-517.

Nakanishi, M., O. Mitamura and T. Matsubara (1990): Sestonic C:N:P ratios in the south basin of Lake Biwa with special attention to nutritional state of phytoplankton. Jpn. J. Limnol., $51: 185-189$.

Nakano, S. (1994a): Carbon: nitrogen: phosphorus ratios and nutrient regeneration of a heterotrophic flagellate fed on bacteria with different elemental ratios. Arch. Hydrobiol., 129 : 257271.

Nakano, S. (1994b) : Rates and ratios of nitrogen and phosphorus released by a bacterivorous flagellate. Jpn. J. Limnol., 55 : 115-123.

Sakamoto, M. (1966) : Primary production by phytoplankton community in some Japanese lakes and its dependence on lake depth. Arch. Hydrobiol., 62 : 1-28.

Sanders, R. W., K. G. Porter, S. J. Bennet and A. E. DeBiase (1989): Seasonal patterns of bacterivory by flagellates, ciliates, rotifers, and cladocerans in a freshwater planktonic commu- nity. Limnol. Oceanogr., 34:673-687.

SCHINDLER, D. W. (1978) : Factors regulating phytoplankton production and standing crop in the world's freshwaters. Limnol. Oceanogr., 23 : 478-486.

SHERR, E. B. and B. F. SherR (1983) : Double-staining epifluorescence technique to assess frequency of dividing cells and bacterivory in natural populations of heterotrophic microprotozoa. Appl. Environ. Microbiol,, 46 : 1388-1393.

Sherr, B. F., E. B. Sherr and R. D. Fallon (1987): Use of monodispersed, fluorescently labeled bacteria to estimate in situ protozoan bacterivory. Appl. Environ. Microbiol., 53 : 958-965.

Sterner, R. W. (1990): The ratio of nitrogen to phosphorus resupplied by herbivores: zooplankton and the algal competitive arena. Am. Nat., $138:$ 209-229.

TezuKa, Y. (1985) : C:N:P ratios of seston in Lake Biwa as indicators of nutrient deficiency in phytoplankton and decomposition process of hypolimnetic particulate matter. Jpn. J. Limnol., $46: 239-246$.

TezuKa, Y. (1986): Does the seston of Lake Biwa release dissolved inorganic nitrogen and phosphorus during aerobic decomposition?: Its implication for eutrophication. Ecol. Res., 1: 293-302.

Tezura, Y. (1989) : The C:N:P ratio of phytoplankton determines the relative amounts of dissolved inorganic nitrogen and phosphorus released during aerobic decomposition. Hydrobiologia, 173 : 55-62.

Tezuka, Y. (1990): Bacterial regeneration of ammonium and phosphate as affected by the carbon: nitrogen: phosphorus ratio of organic substrates. Microb. Ecol., $19: 227-238$.

URABE, J. (1993): $N$ and $P$ cycling coupled by grazer's activities: food quality and nutrient release by zooplankton. Ecology, 74:23372350.

Urabe, J., M. Nakanishi and K. Kawabata (in press): Contribution of metazoan plankton to the cycling of $\mathrm{N}$ and $\mathrm{P}$ in Lake Biwa. Limnol. Oceanogr.

Vaustein, O., A. Jensen, Y. Olsen and H. Reinertsen (1988): Growth and phosphorus status of limnetic phytoplankton and bacteria. Limnol. Oceanogr., $33:$ 489-503.

Vadstein, O., Y. Olsen, H. Reinertsen and A. Jensen (1993) : The role of planktonic bacteria in phosphorus cycling in lakes-Sink and link. Limnol. Oceanogr., 38 : 1539-1544. 
Watanabe, Y. (1990): C:N:P ratios of sizefractionated seston and planktonic organisms in various trophic levels. Verh. Internat. Verein. Limnol., 24 : 195-199.

(著者: 中野伸一*, 京都大学生態学研究センター, 于 520-01 滋賀県大津市下阪本 4丁目 1-23； *現在, 滋 賀県琵琶湖研究所, $\overline{5} 520$ 滋賀県大津市打出浜 1 番 10 号; Shin-ichi NAKano*, Center for Ecological Research, Kyoto University, Shimosakamoto, Otsu, Shiga 520-01; *Present address: Lake Biwa Research Institute, 1-10 Uchidehama, Otsu 520 Japan)

Received : 23 April 1994

Accepted : 29 July 1994 